\title{
Kedudukan Lembaga Perbankan Sebagai Pembeli Lelang Eksekusi Hak Tanggungan Atas Jaminanya
}

\author{
I Dewa Gede Agung Dhira Natsya Ora ${ }^{1}$, Dewa Gde Rudy ${ }^{2}$
}

${ }^{1}$ Kantor Konsultan Hukum Dalcon Consulting, E-mail: dewanatsyora@gmail.com 2Fakultas Hukum Universitas Udayana, E-mail: dewarudy1959@gmail.com

\begin{tabular}{l}
\hline Info Artikel \\
\hline Masuk: 12 Maret 2021 \\
Diterima:23 Juni 2021 \\
Terbit: 1 Juli 2021 \\
Keyword: \\
Bank, Auction, Guarantee \\
\\
Kata kunci: \\
Bank, Lelang, Jaminan \\
Corresponding Author: \\
I Dewa GedeAgung Dhira \\
Natsya Ora, E-mail: \\
dewanatsyora@gmail.com \\
DOI: \\
10.24843/AC.2021.v06.i02.p08
\end{tabular}

\begin{abstract}
This paper aim to develops knowledge in the field of notarial law and finds out the difference in legal standing between Rural Banks and Commercial Banks included Regional Development Banks as buyers in the auction for the executions of collateral for their collateral. Normative legal research methods is uses for this writing. The result of this study indicates that Rural Banks and Commercial Banks have different positions in the purchase of a collateral execution auction. Only Commercial Banks that stipulated in Article 12 A parag raph (1) of the Banking Act can purchase an auction for the executions of mortgage guarantees, while Rural Banks cannot become buyers in the auction for executions of collateral for their collateral.
\end{abstract}

\section{Pendahuluan}

\begin{tabular}{l}
\hline Abstrak \\
\hline Tulisan ini bertujuan untuk mengembangkan keilmuan dalam \\
bidang hukum kenotariatan dan untuk mengetahui perbedaan \\
kedudukanhukumantaraBank Perkreditan Rakyat dengan Bank \\
Umum termasuk didalamnya Bank Pembangunan Daerah \\
sebagai pembeli dalam lelang eksekusi hak tanggungan atas \\
jaminannya. Penelitian ini menggunakan metode penelitian \\
hukum normatif. Hasil penelitian ini membuktikan bahwa Bank \\
Perkreditan Rakyat dengan Bank Umum memiliki perbedaan \\
kedudukan dalam pembelian lelang eksekusi hak tanggungan \\
atasjaminannya. Bankyang dapat membeli lelang eksekusi hak \\
tanggungan atas jaminannya hanyalah Bank Umum \\
sebagaimana yang diatur dalam Pasal 12 Aayat (1) Undang- \\
Undang Perbankan, sedangkan Bank Perkreditan Rakyat tidak \\
dapat menjadi pembeli dalam lelang eksekusi hak tanggungan \\
atas jaminannya.
\end{tabular}

Bank merupakan lembaga sebagai wujud dari kepercayaan, tanpa adanya suatu kepercayaan maka lembaga perbankan tidak akan dapat berdiri dengan tegak sehingga kepercayaan sendiri sebagai sesuatu yang paling penting untuk dibangun maupun dipertahankan pihak Bank secara terus menerus. Bank dapat diartikan sebagai suatu badan usaha penyalur dana berupa kredit maupun bentuk yang lain 
kepada masyarakat, selain sebagai penyalur dana bank juga sebagai badan usaha penghimpun dana masyarakat berupa simpanan, penyaluran maupun penghimpunan dana oleh bank tersebut dimaksudkan untuk meningkatkan taraf hidup dari masyarakat. Sehingga dengan demikian bank dapat dikatakan memiliki fungsi intermediasi. ${ }^{1}$ Menurut jenisnya, berdasarkan Undang-Undang No. 10 Tahun 1998 sebelumnya Undang-Undang No. 7 Tahun 1992 Pasal 5 berikutnya sebagai UndangUndang Perbankan yaitu Bank Umum dan Bank Perkreditan Rakyat. Perbedaan mendasar Bank Umum termasuk didalamnya Bank Pembangunan Daerah berdasarkan Pasal 21 ayat (3) huruf c, hanya bisa melayani pada jasa transaksi pembayaran, memberikan layanan serupa oleh Bank Perkreditan Rakyat dilarang atau tidak dapat dilayani. Merujuk dari penjelasan Undang-Undang tersebut menyebabkan Bank Perkreditan Rakyat lebih memilih pada sektor UMKM (Usaha Kecil dan Menengah) menjadi segmen pasar dominan atau mayoritas nasabah dari Bank Perkreditan Rakyat karena atas perbedaan jasa tersebut.

Suatu lembaga bank memberikan hanya jasa layanan yang dapat berupa penyimpanan dana melalui tabungan atau deposito serta penyaluran dana kepada masyarakat dalam bentuk kredit adalah pengertian dari Bank Perkreditan Rakyat. Sehingga dengan demikian, kesehatan kredit menjadi sangat penting bagi Bank Perkreditan Rakyat karena selain sebagai indikator kesehatan dari bank, kredit juga menjadi sumber pendapatan bagi Bank Perkreditan Rakyat. Dalam menjalankan fungsi intermediasi, Bank Perkreditan Rakyat menyalurkan dana Nasabah Penyimpan melalui kredit kepada Nasabah Peminjam. Penyaluran dana dalam bentuk kredit tidak seluruhnya berjalan dengan lancar dan menjadi suatu permasalah besar jika uang yang telah disalurkan oleh Bank Perkreditan Rakyat melalui pemberian kredit kepada Nasabah Peminjam tidak dapat kembali atau tidak mampu membayar cicilan baik pokok dan bunganya atau dengan kata lain terdapat tunggakan kewajiban kredit dari Nasabah Peminjam. Tunggakan kredit tersebut tentu akan sangat berdampak pada kesehatan bank dan dapat mengganggu likuiditas dari Bank Perkreditan Rakyat itu sendiri, sehingga secara tidak langsung dapat merugikan Nasabah Penyimpan jika Bank Perkreditan Rakyat tidak mampu mempertahankan likuiditasnya yang dikarenakan banyaknya penyaluran kredit macet atau nasabah tidak mampu bayar.

Bank Perkreditan Rakyat selaku penyalur kredit tentu akan mendahulukan proses penyelamatan terhadap kredit yang bermasalah sepanjang nasabah memiliki pemasukan dengan arus kas lancer dari bisnis atau usaha cukup sehat, tangguh dan terbukti baik serta terus tumbuh berkembang walaupun situasi perekonomian semakin sulit. Sebagai upaya langkah penyelamatan terhadap kredit yang bermasalah diatas diambil langkah-langkah seperti dijadwalkan ulang (rescheduling), disyaratkan ulang (reconditioning) dan ditata ulang (restructuring). Setelah dilakukan usaha tersebut dengan beberapa cara tersebut namun kredit tetap tidak dapat diselamatkan atau Nasabah Peminjam berdasarkan penilaian Bank Perkreditan Rakyat tidak mampu lagi sebagai prospek usahanya yang tidak sehat dan dianalisa sulit tumbuh dan berkembang, maka jalan satu-satunya dan terakhir yang boleh dijalani Bank Perkreditan Rakyat yaitu melakukan eksekusi terhadap barang yang dipergunakan sebagai jaminan untuk memperoleh fasilitas kredit. Pelaksanaan eksekusi jaminan

\footnotetext{
AliSuyanto Herli (2013), Buku Pintar Pengelolaan BPR dan Lembaga Keuangan Pembiayaan Mikro, Yogyakarta : ANDI Yogyakarta, h 3.
} 
terhadap kredit yang bermasalah, dilakukan dengan penjualan jaminan melalui lelang yang didasarkan pada Undang-Undang Hak Tanggungan (UUHT) dalam UndangUndang No. 4 Tahun 1996 Pasal 6. Terkait Hak Tanggungan pendapat Kartini Muljadi dan Gunawan Widjaja bahwa sebagai hak jaminan kebendaan diperuntukan sebagai melunasi kredit, melalui bidang tanah yang telah dijaminkan dengan Hak Tanggungan itu dijual mandiri, berikutnya mendapat pembayaran lunas atas nilai lelang itu sampai sesuai dengan nilai piutang kreditur atau Hak Tanggungan. ${ }^{2}$

Lelang dapat diartikan sebagai perjanjian jual beli barang jaminan karena lelang sebagai suatu sarana yang dapat dipakai untuk pertemuan antara penjual dengan pembeli dengan tujuan untuk bisa ditentukan harga sewajarnya terhadap jaminan. Di Indonesia dalam Vendu Reglement diatur pengaturan mengenai hal itu atau dengan Undang-Undang Lelang yang disebut juga mengatur mengenai pokok-pokok penjualan dimuka umum atau lelang. ${ }^{3}$ Vendu Reglement dalam Pasal 1 memberikan definisi atas lelang sebagai penjualan umum yaitu "penjualan barang-barang yang dilakukan kepada umum dengan penawaran harga yang meningkat atau menurun atau dengan pemasukan harga dalam sampul tertutup, atau kepada orang-orang yang diundang atau sebelumnya diberitahu mengenai pelelangan atau penjualan itu, atau diizinkan untuk ikut serta, dan diberi kesempatan untuk menawar harga, menyetujui harga yang ditawarkan atau memasukkan harga dalam sampul tertutup." Vendu Reglement atau Undang-Undang Lelang memiliki peraturan dibawahnya sebagai peraturan pelaksana terhadap ketentuan lelang. Peraturan pelaksana tersebut dituangkan Peraturan Menteri Keuangan terkait Petunjuk Pelaksanaan Lelang berikutnya sebagai PMK No. 27/PMK. 06/2016.

Diatur dalam Pasal 1 angka 1 dalam UUHT: "hak jaminan yang dibebankan pada hak atas tanah sebagaimana dimaksud dalam Undang-Undang Nomor 5 Tahun 1960 tentang Peraturan Dasar Pokok-Pokok Agraria, berikut atau tidak berikut benda-benda lain yang merupakan satu kesatuan dengan tanah itu, untuk pelunasan utang tertentu, yang memberikan kedudukan yang diutamakan kepada kreditor tertentu terhadap kreditor-kreditor lainnya." disebut sebagai Hak Tanggungan. Peran mediasi dimiliki oleh lembaga perbankan yaitu sebagai penghimpun dana dari nasabah dan sebagai penyalur kembali berupa pinjaman untuk nasabah atau debitur. Penerapan Prinsip kehati-hatian (prudential banking) selaku kreditur Bank wajib agar terhadap penyaluran pinjaman. ${ }^{4}$ Agar mencegah terjadinya risiko kredit yang gagal atau macet, maka bank selaku kreditur mewajibkan syarat jaminan harus ada dalam pengajuan kredit terutama kredit dengan pengajuan bernilai besar. Salah satu dari persyaratan pengajuan kredit adalah dengan pemberian hak tanggungan terkait sertifikat tanah yang diberikan sebagai jaminan merupakan perjanjian tambahan dari perjanjian kredit.

\footnotetext{
${ }^{2}$ Kartini Muljadi dan Gunawan Widjaja, Seri Hukum Harta Kekayaan, Hak Tanggungan, Kencana, Jakarta, 2008, h. 180

${ }^{3}$ Rachmadi Usman. (2016). Hukum Lelang. Januari: Sinar Grafika. h. 15.

${ }^{4}$ Susanto, A., Rotinsulu, T. O., \& Kawung, G. M. (2019). Analisis Faktor-faktor yang Mempengaruhi Keberhasilan Lelang Eksekusi Hak Tanggungan pada Kantor Pelayanan Kekayaan Negara dan Lelang Palu (2015-September 2016). JURNAL PEMBANGUNAN EKONOMI DAN KEUANGAN DAERAH,19(1), h. $2 . \quad$ doi: https://doi.org/10.35794/jpekd.15776.19.1.2017
} 
Sesuai ketentuan dari Pasal 6: "apabila debitur cidera janji, pemegang hak tanggungan pertama mempunyai hak untuk menjual objek Hak Tanggungan atas kekuasaan sendiri melalui pelelangan umum serta mengambil pelunasan piutangnya dari hasil penjualan tersebut". Cara penjualan didasarkan pada Pasal 6 tersebut sebagai bentuk penyelesaian dengan cara cepat dan memerlukan biaya lebih sedikit daripada melalui cara berbeda adalah Lelang. Sehingga dengan demikian, apabila cara penyelamatan jaminan atas kredit tidak dapat atau tidak bisa lagi dilakukan maka, penjualan melalui cara lelang tersebut adalah merupakan pilihan bank sebagai kreditur jika debitur tidak dapat atau gagal dalam menyelesaikan kewajiban sebagaimana mestinya. Namun, terdapat suatu permasalahan yang akan terjadi, ketika tidak ter dapatnya pembeli yang membeli barang jaminan yang dijual melalui hak tanggungan dieksekusi secara lelang sesuai pada Pasal 6, Undang -Undang Hak Tanggungan itu sendiri.

Pembentukan Penyisihan Penghapusan Aset Produktif dan Kualitas Aset Produktif dari Bank Perkreditan Rakyat dalam ketentuan ketentuan No. 33/POJK.03/.2018 Peraturan Otoritas Jasa Keuangan didalam angka 10 dalam Pasal 1 yang berikutnya disebut POJK No. 33/POJK 03/2018, mengatur sebagaimana "Agunan Yang Diambil Alih yang selanjutnya disebut AYDA adalah aset yang diperoleh BPR untuk menyelesaikan kredit, baik melalui pelelangan, atau diluar pelelangan berdasarkan penyerahan secara sukarela oleh pemilik agunan atau berdasarkan surat kuasa untuk menjual di luar lelang dari pemilik agunan, dalam hal Debitur telah dinyatakan macet", dalam ketentuan tersebut secara eksplisit mengatur dalam hal menyelesaian kredit Bank Perkreditan Rakyat dapat memperoleh dan/atau membeli aset Nasabah Peminjam yang telah dinyatakan macet melalui cara pelelangan. Namun ketentuan tersebut tidak sejalan sesuai tercantum dalam Pasal 12 A Undang-Undang Perbankan dalam ayat (1) yaitu "Bank Umum dapat membeli sebagian atau seluruh agunan, baik melalui pelelangan maupun diluar pelelangan berdasarkan penyerahan secara sukarela oleh pemilik agunan dalam hal Nasabah Debitur tidak memenuhi kewajibannya kepada bank, dengan ketentuan agunan yang dibeli tersebut wajib dicairkan secepatnya". Dalam ketentuan pasal tersebut hanya menyebutkan bank umum saja yang dapat membeli agunan melalui mekanisme pelelangan dari jaminan terhadap kredit yang dinyatakan macet atau kredit gagal. Dengan demikian terjadi konflik norma yang dapat menimbulkan suatu ketidakpastian hukum bagi masyarakat pada umumnya dan khususnya untuk Bank Perkreditan Rakyat serta nasabah dari Bank Perkreditan Rakyat itu sendiri.

Dalam penelitian ini, dikaji permasalahan yaitu konflik norma hukum yang terjadi antara Peraturan Otoritas Jasa Keuangan Pasal 1 angka 10 POJK No. 33/POJK.03/2018 dengan ayat (1) Pasal 12 A Undang-Undang Perbankan. Penelitian ini mengkaji rumusan masalah yaitu bagaimana perbedaan kedudukan hukum antara Bank Perkreditan Rakyat dengan Bank Umum sebagai pembeli dalam lelang eksekusi hak tanggungan atas jaminannya? Penulisan Penelitian ini bertujuan mengembangkan keilmuan bidang hukum kenotariatan dan untuk mengetahui perbedaan kedudukan hukum antara Bank Perkreditan Rakyat dengan Bank Umum sebagai pembeli dalam lelang eksekusi hak tanggungan atas jaminannya, yang berawal dari konflik norma hukum tersebut.

Terkait dengan penelitian ini terdapat beberapa penelitian sebelumnya, yaitu oleh Chadijah Rizki Lestari pada tahun 2017 yang menyimpulkan bahwa adanya kredit 
macet dalam suatu bank merupakan sesuatu yang tidak dapat dihindari, sehingga apabila hal tersebut terjadi dan kredit itu tidak dapat diselamatkan lagi maka bank dapat mengambil pelunasan piutang dengan lelang yang atas objek hak tanggungan dilaksanakan dengan eksekusi melalui Kantor Pelayanan Kekayaan Negara dan Lelang sesuai ketentuan Pasal 6 UUHT. 5 Sejalan dengan penelitian tersebut Utari Herman dan Ratna Widayanti pada tahun 2019 dalam penelitiannya menyimpulkan bahwa terhadap kredit bermasalah diselesaikan dengan mengirim Surat Peringatan (SP) 1 (satu) sampai 3 (tiga), dan yang terakhir penyelesaian dilakukan melalui suatu pelelangan umum. 6 Selanjutnya, Pada tahun 2016 terkait Penelitian tentang Perbedaan Bank Umum dan Bank Perkreditan Rakyat, Jesica Sumual pembahasan penelitiannya memberikan batasan terhadap perbedaan dari Bank Umum dan Bank Perkreditan Rakyat terkait tugas serta fungsinya,. Bank Umum dalam penelitian tersebut yang memiliki lebih besar terkait tugas dan fungsi dibandingkan dengan Bank Perkreditan Rakyat seperti misalnya dalam menerbitkan surat pengakuan utang, menghimpun dana dalam bentuk giro dan sebagainya. ${ }^{7}$ Putu Devi Yustisia Utami pada tahun 2019 Terkait Kajian Yuridis Agunan Yang Diambil Alih (AYDA) oleh Bank, dalam penelitiannya menyimpulkan bahwa menyelesaikan pinjaman macet wajib mengeksekusi hak tanggungan sesuai Pasal 20 UUHT. 8

Dari keempat penelitian tersebut mempunyai fokus yang tidak sama dengan penelitian ini, dalam penelitian ini dikaji permasalahan yaitu konflik norma hukum yang terjadi antara Peraturan Otoritas Jasa Keuangan Pasal 1 angka 10 POJK No. 33/POJK.03/2018 dengan ayat (1) Pasal 12 A Undang-Undang Perbankan. Dalam penjabaran Peraturan Otoritas Jasa Keuangan Pasal 1 angka 10 POJK No. 33/POJK.03/2018 mengatur bahwa Bank Perkreditan Rakyat dapat memperoleh/ membeli aset Nasabah Peminjam yang telah dinyatakan macet melalui pelelangan sedangkan dalam Undang-Undang Perbankan ayat (1) Pasal 12 A yang dapat memperoleh/ membeli aset Nasabah Peminjam adalah Bank Umum termasuk didalamnya Bank Pembangunan Daerah. Konflik norma hukum yang terjadi tersebut merupakan fokus peneliti sebagai bentuk orisinalitas dari hal yang diteliti.

\section{Metode Penelitian}

Dalam penelitian ini digunakan metode penelitian hukum normatif dikarenakan kajian dari metode ini menguraikan permasalahan terkait konflik norma hukum yang terjadi antara Peraturan Otoritas Jasa Keuangan Pasal 1 angka 10 POJK No. 33/POJK.03/2018 dengan ayat (1) Pasal 12 A Undang-Undang Perbankan. Penelitian ini menggunakan jenis pendekatan antara lain pendekatan Peraturan Perundang-Undangan (statute approach) dan pendekatan konseptual (conceptual approach), pendekatan tersebut dipergunakan memaparkan dan menganalisis permasalahan yang diteliti bermulai

\footnotetext{
5 Lestari, C. R. (2017). Penyelesaian Kredit Macet Bank Melalui Parate Eksekusi. Kanun Jurnal Ilmu Hukum, 19(1), 81-96, h. 94. http:/ / www.jurnal.unsyiah.ac.id/kanun/article/view / 6600

${ }^{6}$ Widayati, R., \& Herman, U. (2019). Penyelesaian Kredit Bermasalah Pada PT. Bank Perkreditan Rakyat (BPR) Nagari Kasang, h. 12. doi: https://doi.org/10.31219/osf.io/d738z

${ }^{7}$ Sumual, J. (2016). Perbedaan Bank Umum dan Bank Perkreditan Rakyat terhadap Tugas dan Fungsi Bank menurut Undang-Undang Nomor 10 Tahun1998. Lex Administratum, 4(3).h. 95. https:/ / ejournal.unsrat.ac.id/index.php/administratum/article/view/11508

8 Utami, P. D. Y. (2019). KAJIAN YURIDIS AGUNAN YANG DIAMBIL ALIH (AYDA) OLEH BANK. Kerta Dyatmika, 16(2), 69-77. doi: https:// doi.org/10.46650/kd.16.2.739.69-77
} 
dengan terdapatnya ketentuan hukum yang berkonflik kemudian ditelaah berdasarkan hierarki Peraturan Perundang-Undangan. ${ }^{9}$ Pengertian Pendekatan Konseptual yaitu dengan menyelesaikan dengan menelaah dilihat melalui sisi konsepkonsep hukum sebagai latar belakang hal tersebut sedangkan Pendekatan Peraturan Perundangan-Undangan dengan mengkaji seluruh peraturan perundang-undangan terkait permasalahan hukum yang diteliti. Kedua pendekatan tersebut dipergunakan untuk memaparkan dan mengupas pembahasan terkait penelitian yang berawal pada terdapatnya konflik norma hukum yang ditelaah berdasarkan jenis dan hierarki Peraturan Perundang-Undangan. Dipergunakan 3 (tiga) sumber bahan hukum dalam penelitian ini, pertama yaitu meliputi jurnal-jurnal nasional atau bahan hukum primer, jurnal-jurnal internasional, tesis maupun disertasi, yang kedua yaitu meliputi beberapa buku-buku terkait atau bahan hukum sekunder, serta ketiga yaitu seperti misalnya kamus hukum atau bahan hukum tertier. Teknik studi dokumen, serta dengan analisis deskriptif atas analisis kajian yang dilakukan secara sistematis sebagai teknik penelusuran bahan hukum dalam penelitian ini.

\section{Hasil Dan Pembahasan}

Kredit yang bermasalah merupakan suatu bentuk permasalahan sendiri yang harus diselesaikan oleh Bank Perkreditan Rakyat. Tingginya persentase kredit yang bermasalah akan berdampak pada kesehatan bank itu sendiri yang selanjutnya dapat menurunkan tingkat kepercayaan khususnya dari Nasabah Penyimpan dan masyarakat pada umumnya. Selain hal tersebut, Penyaluran Kredit merupakan satusatunya sumber dari pendapatan bagi Bank Perkreditan Rakyat sehingga merupakan suatu keharusan bagi Bank Perkreditan Rakyat untuk melakukan penyelesaian kredit macet atau gagal yang bermasalah secara tepat dan cepat berdasarkan norma hukum yang berlaku. Pinjaman yang macet tersebut secara garis besar dilakukan dengan mekanisme penyelesaian dan penyelamatan kredit.

Pada lembaga perbankan dikenal adanya penyelamatan kredit bermasalah dengan istilah restrukturisasi kredit. Ini merupakan upaya yang dilakukan untuk memperbaiki suatu lembaga perbankan pada umumnya dan dalam kegiatan perkreditan khususnya pada Bank Perkreditan Rakyat, Nasabah Peminjam yang menghadapi kesulitan dalam melakukan kewajiban membayar kewajiban. Restrukturisasi kredit tersebut tidak dapat diberikan kepada semua Nasabah Peminjam, hal tersebut dikarenakan selain hanya dapat diberikan kepada Nasabah Peminjam yang sulit dalam membayar pokok utang dan/atau bunganya, Bank mesti menilai mengenai prospek usaha Nasabah Peminjam, dengan harapan setelah dilakukan restrukturisasi kredit usaha Nasabah Peminjam/ debitur akan mampu tumbuh dan pada akhirnya dapat menyelesaikan pinjaman kredit. Restrukturisasi kredit dapat dilakukan dengan skema dijadwalkan ulang (rescheduling), ditata ulang (restructuring), dan disyaratkan ulang (reconditioning). ${ }^{10}$ Pengertian Jadwal ulang (rescheduling) adalah dirubah syarat pinjaman yang terkait rencana pelunasan maupun batas waktu kredit termasuk masa

9 I Made Pasek Diantha. (2016). Metodologi Penelitian Hukum Normatif dalam Justifikasi Teori Hukum. Jakarta: Prenada Media Group. h. 159.

${ }^{10}$ Jufri, S., Borahima, A., \& Said, N. (2020). Pelaksanaan Lelang Eksekusi Hak Tanggungan Melalui Balai Lelang. Jurnal Ilmiah Dunia Hukum,4(2), 95-107, h. 97. doi: http://dx.doi.org/10.35973/jidh.v4i2.1379 
tenggangnya dengan merubah besar kecil angsurannya, Penataan ulang (restructuring atau Recapitalizing) merupakan langkah dari Bank kepada nasabahnya dengan cara memberikan tambahan modal usaha sesuai pertimbangan dari nasabah yang sedang perlu dana tambahan agar usahanya dapat dibiayai sehingga dapat memberikan hasil yang dapat meningkatkan arus kas (cash flow) dari usaha nasabah sedangkan disyaratkan ulang (reconditioning) yaitu dirubahnya seluruh atau sebagian dari syaratsyarat kredit seperti merubah jadwal bayar, waktu bayar atau sejenisnya apabila tanpa melakukan penyesuaian terhadap nilai tertinggi dari batas maksimal plafon kredit yang telah diajukan. Terhadap Nasabah Peminjam yang oleh penilaian bank tidak memenuhi syarat untuk dapat dilakukan restrukturisasi kredit, maka penanganan kredit bermasalah dilakukan dengan skema penyelesaian kredit.

Penyelesaian kredit adalah skema penanganan permasalahan kredit dengan pelunasan kredit. Pelunasan kredit dapat dilakukan dengan pelunasan atau pembayaran langsung seluruh kewajiban oleh Nasabah Peminjam atau dengan penjualan objek jaminan. Terkait dengan penjualan objek jaminan dapat dilakukan dengan upaya sukarela maupun upaya paksa. Upaya penjualan objek jaminan secara sukarela oleh Nasabah Peminjam dilakukan dengan persetujuan Nasabah Peminjam untuk menjual objek jaminan dengan hasil penjualan tersebut dipergunakan untuk melunasi kredit. Sedangkan upaya penjualan objek jaminan secara paksa dilakukan oleh Bank yaitu penjualan melalui lelang Pada Kantor Pelayanan Kekayaan Negara melalui perantara Pejabat Lelang, eksekusi dimohonkan oleh Bank melalui mekanisme lelang.

Suatu perbuatan hukum jual beli salah satunya adalah lelang, sehingga terdapat pembeli lelang dan penjual atau pemohon lelang. Pemilik barang dapat diartikan sebagai owner, seller, vendor atau disebut pemohon lelang, bisa diajukan oleh perorangan, badan hukum atau badan usaha sesuai undang-undang atau perjanjian memiliki wewenang menjadi penjual melalui pelelangan. Pemohon lelang atau pemilik atas barang yaitu penjual yaitu orang atau badan hukum pemilik hak kepemilikan dari barang lelangan. Dalam lelang baik pemohon atau penjual lelang bisa juga memiliki status dengan surat kuasa dari pemilik jaminan atau perorangan atau badan hukum dapat menjual jaminan tersebut melalui proses lelang sesuai undang-undang yang berlaku yang memberikan kewenangan. Selanjutnya, dalam lelang juga terdapat peserta atau pembeli lelang atau disebut juga attenders, bidders, the highest bidders, buyers. Penawar atau pemohon lelang yaitu Perorangan maupun badan usaha badan atau hukum usaha dinyatakan sah saat lelang menjadi pihak juara/menang dari pejabat lelang melalui pengajuan penawaran paling tinggi dengan tercapainya atau terlampaui batas nilai limit yang kemudian. Diantara beberapa jenis lelang seperti dapat berupa:

1. Lelang Eksekusi yaitu jual beli jaminan sebagai realisasi dari hasil sidang atau yang ditetapkan oleh majelis hukum atau dalam rangka pelaksanaan dalam ketentuan aturan hukum yang berlaku.

2. Lelang Non Eksekusi Wajib yaitu jual beli jaminan menurut ketentuan aturan hukum yang berlaku wajib dijual rangka pelaksanaan menjual barang jaminan.

3. Lelang Non Eksekusi Sukarela yaitu dilelang secara sukarela dari jaminan kepemilikan jaminan baik hak dari pribadi/orang atau badan.

Lelang dimulai dengan penawaran suatu harga yang dimulai dengan angka minimum tertentu disebut sebagai nilai limit (reserve price). Nilai limit berdasarkan ketentuan 
mengenai Petunjuk Pelaksanaan Lelang angka 28 Pasal 1 dalam PMKNo .27/PMK06/2016 yaitu "harga minimal barang yang akan dilelang dan ditetapkan oleh Penjual". Pejabat lelang membuka harga sesuai dengan nilai limit dari barang yang dijual, kemudian peserta lelang melakukan penawaran yang nilainya terus naik hingga ditemukan penawar dengan nilai tertinggi. Setelah ditemukan peserta yang melakukan penawaran lelang tertinggi dan yang lain tidak ada yang melakukan penawaran lebih tinggi lagi, sehingga oleh pejabat dalam lelang terhadap peserta yang menawar dengan harga tertinggi disahkan sebagai pembeli lelang. Pemenang lelang akan menyetor uang jaminan sebagai pemenang lelang ke dalam rekening KPKNL atau Balai Lelang lewat Bank yang telah ditunjuk didalam pengumuman lelang dengan besaran antara $20 \%$ hingga 50\% dari harga limit lelang. Penjualan Jaminan dalam lelang walaupun masuk sebagai jual beli tetapi mempunyai unsur-unsur antara lain: Sifat jual barang yang dibuka untuk umum, setiap penawaran berdasarkan atas kompetisi antar peserta lelang, dimulai dari dikumpulkannya calon peminat sebagai peserta dalam lelang dengan diumumkan dalam pengumuman lelang, oleh dan atau dihadapan pejabat lelang penjualan barang jaminan wajib dilakukan.

Unsur-unsur inilah menjadi dasar, setiap dilaksanakan lelang dimulai dengan pemberitahuan informasi terkait barang jaminan yang akan dilelang atau dinamai sebagai pengumuman lelang. Pengumuman lelang sebagai hal wajib adanya dalam setiap pelaksanaan lelang sebagai bentuk pemberitahuan kepada masyarakat terkait akan adanya lenang supaya terkumpulnya para peminat lelang dan diberitahukan kepada pihak yang memiliki kepentingan sebagaimana PMK No .27/PMK06/20 16 mengenai Petunjuk Pelaksanaan Lelang dalam Pasal 51, pada setiap pengumumannya dengan media cetak serta elektronik. Sesuai PMK Nomor 27/PMK .06/201 6 Pasal 52 ayat (1) mengenai Petunjuk Pelaksanaan Lelang, pengumumannya wajib mencantumkan: identitas; waktu, hari, tanggal, dan tempat/ lokasi dilaksanakan dimana; dan seterusnya sesuai penjabarannya termasuk waktu dan tempat anwijzing, melakukan aanwijzing oleh penjual; jaminan penawaran lelang seperti satuan/ besarannya, dan seterusnya sesuai penjabarannya, jika ada syarat tambahan lain dari penjual. Aanwijzing dapat diartikan sebagai salah satu tahapan atau proses pemberian penjelasan di dalam sebuah lelang atas jaminan nasabah,wajib diikuti oleh peminat dan perserta lelang.

Melalui lelang penjualan tidak selalu laku terjual, seringkali dalam penjualan lelang dengan suatu objek jaminan lelang dijual berkali-kali dalam lelang pertama, kedua bahkan ketiga karena tidak adanya peminat atau pembeli lelang. Pasal 1 angka 10 POJK No. 33/POJK.03/2018 menyatakan bahwa "Agunan Yang Diambil Alih yang selanjutnya disebut AYDA adalah aset yang diperoleh BPR untuk menyelesaikan kredit, baik melalui pelelangan, atau diluar pelelangan berdasarkan penyerahan secara sukarela oleh pemilik agunan atau berdasarkan surat kuasa untuk menjual di luar lelang dari pemilik agunan, dalam hal Debitur telah dinyatakan macet" yang mana ketentuan tersebut secara eksplisit menyatakan bahwa proses kred it bermasalah diselesaikan, Bank Perkreditan Rakyat bisa memperoleh atau membayar dengan beli aset yang menjadi jaminan kredit Nasabah Peminjam yang telah dinyatakan macet melalui pelelangan. Diambil Alihnya Agunan ialah aset yang didapat pihak Bank dari proses lelang ataupun dari luar lelang sesuai dengan penyerahan jaminan atau agunan tanpa paksaan atau secara sukarela oleh nasabah dengan dasar surat kuasa untuk 
menjual jaminan tersebut karena nasabah tidak dapat memenuhi kewajibannya. Lebih lanjut ketentuan tersebut juga sejalan dengan ketentuan mengenai Petunjuk Pelaksanaan Lelang ayat (1) Pasal 78 PMK No. 106/PMK.06/2013 mengatur bahwa “Bank sebagai kreditur dapat membeli agunan melalui lelang, dengan ketentuan menyampaikan surat pernyataan dalam bentuk Akta Notaris, bahwa pembelian tersebut dilakukan untuk pihak lain yang akan ditunjuk kemudian dalam jangka waktu 1 (satu) tahun terhitung mulai tanggal pelaksanaan lelang". Ketentuan PMK No.106/PMK06/2013 ayat (1) Pasal 78 tersebut, tegas menempatkan yaitu Bank Umum dan Bank Perkreditan Rakyat sesuai UU Perbankan dalam Pasal 5, dalam kedudukannya selaku Kreditur dapat melakukan pembelian untuk seseorang yang akan ditunjuk kemudian (acte de command) atas pembelian agunan miliknya, dan apabila jangka waktu yang diberikan terlampaui maka Bank (Bank Umum maupun Bank Perkreditan Rakyat) selaku Kreditur secara mutatis mutandis ditempatkan sebagai pembeli. Pengertian secara mutatis mutandis artinya sesuai dengan kondisi yang mendesak sangat perlu atau penting dilakukan perubahan prosedur pada hal penting yang diperlukan.

Ketentuan yang memperbolehkan Bank Perkreditan Rakyat membeli agunan Nasabah Peminjam berdasarkan dalam Pasal 6 tak sejalan ketentuan Undang-Undang Perbankan Pasal 12 A. Dalam ayat (1) Pasal 12 A mengatur "Bank Umum dapat membeli sebagian atau seluruh agunan, baik melalui pelelangan maupun diluar pelelangan berdasarkan penyerahan secara sukarela oleh pemilik agunan dalam hal Nasabah Debitur tidak memenuhi kewajibannya kepada bank, dengan ketentuan agunan yang dibeli tersebut wajib dicairkan secepatnya", ketentuan tersebut secara eksplisit menentukan hanya Bank Umum yang memiliki kewenangan untuk bisa melakukan pembelian atas agunan dalam lelang. Oleh ketentuan tersebut kemudian ditindaklanjuti oleh Direktorat Lelang, Direktorat Jenderal Kekayaan Negara, Kementerian Keuangan RI sebagaimana surat dengan Nomor S-407/KN.7/2012 tanggal 12 April 2012 perihal Penegasan Terkait Pembeli Lelang Yang Akan Ditunjuk Kemudian Oleh Bank Umum Selaku Kreditur Atas Objek Agunannya yang selanjutnya disebut sebagai Surat Direktorat Lelang No. S-407/KN.7/2012, hanya menafsirkan Bank Umum. Direktorat Lelang, Direktorat Jenderal Kekayaan Negara, Kementerian Keuangan RI melihat ketentuan pasal 12 A Undang-Undang Perbankan secara restriktif (dengan mempersempit kata-kata yang terdapat dalam ketentuan pasal 12 A UndangUndang Perbankan khususnya mengatur mengenai Bank).

Konflik norma adalah kondisi dimana dalam suatu peraturan ada dua norma yang bertentangan satu sama lain sehingga pengaturan terhadap objek tersebut hanya salah satu norma saja dapat diterapkan dan mengesampingkan norma lainnya. Konflik norma dapat bersifat vertikal maupun horizontal, konflik norma vertikal yaitu antara kaidah diatasnya tidak sesuai dengan kaidah dibawahnya sesuai tata jenis dan hierarki Peraturan Perundang-undangan, sedangkan konflik norma horizontal yaitu antara aturan yang memiliki kedudukan sejajar di sesuai tata jenis dan hierarki Peraturan Perundang-undangan. Konflik norma antara ketentuan Pasal 1 angka 10 POJK No. 33/POJK.03/2018 dengan Pasal 12 A ayat (1) Undang-Undang Perbankan berakibat hukum menimbulkan ketidakpastian hukum bagi Bank Perkreditan Rakyat khususnya dan masyarakat umumnya. Berkaitan dengan hal tersebut terjadi tumpang tindih pengaturan antara Pasal 1 angka 10 POJK No. 33/POJK.03/2018 yang memperbolehkan Bank Perkreditan Rakyat sebagai pembeli lelang atas jaminannya 
dengan ketentuan Undang-Undang Perbankan Pasal 12 A ayat (1) mengatur hanya Bank Umum termasuk didalamnya adalah Bank Pembangunan Daerah sesuai Pasal 21 ayat (3) huruf c yang bisa menjadi pembeli lelang atas jaminannya.

Sesuai Undang - Undang No. 12 Tahun 2011 terkait Penyusunan Peraturan PerundangUndangan ditentukan pada ayat (1) Pasal 7 mengatur tentang hierarki peraturan perundang-undangan diatur tentang jenis dan hierarkinya, yang bisa diurutkan dari bawah ke atas : Peraturan Daerah Kabupaten-Kota hingga Undang-Undang Dasar NKRI 1945. Termasuk juga dengan peraturan yang ditetapkan: Gubernur, Bupati/Walikota, Kades, hingga Badan, lembaga, atau komisi maupun Menteri, Bank Indonesia, Komisi Yudisial, Badan Pemeriksa Keuangan, MK, MA, DPD, DPR, dan MPR.

Semua yang disebutkan di atas keberadaannya sangat diakui dan sepanjang undangundang diatasnya memerintahkan maupun dibuat sesuai dengan wewenang maka akan mempunyai kemampuan kekuatan hukum yang mengikat.

Asas preferensi merupakan suatu prinsip sebagai meta aturan yang diterapkan apabila dalam suatu aturan hukum terjadi pertentangan atau konflik antara aturan satu dengan lainnya. Terdapat tiga asas yang termasuk dalam asas preferensi hukum antara lain:

1. Lex Specialis Derogat Legi Generali, berarti aturan hukum yang bersifat khusus mengesampingkan aturan hukum yang bersifat umum.

2. Lex Posterior Derogat Legi Priori, berarti aturan hukum yang baru mengesampingkan aturan hukum yang lama.

3. Lex Superior Derogat Legi Inferiori, berarti aturan hukum yang secara hierarki lebih tinggi mengesampingkan aturan hukum yang hierarkinya lebih rendah. ${ }^{11}$

Sesuai asas Lex Superiori Derogat Legi Inferiori bahwa menghendaki aturan/kaidah yang diatanya tak boleh ditentang dengan yang berada dibawahnya, maka ketentuan POJK No. 33/POJK.03/2018 Pasal 1 angka 10 dikesampingkan karena secara hierarki tidak selaras atau sesuai undang-undang diatasnya yaitu sesuai ketentuan ayat (1) Pasal 12 A Undang-Undang Perbankan. Bahwa yang dapat membeli lelang eksekusi hak tanggungan atas jaminannya hanyalah Bank Umum diatur ketentuan ayat (1) Pasal 12 A. Sehingga dengan demikian, terdapat perbedaan kedudukan hukum antara Bank Perkreditan Rakyat dengan Bank Umum termasuk didalamnya Bank Pembangunan Daerah sebagai pembeli terkait lelang eksekusi hak tanggungan atas jaminannya.

\section{Kesimpulan}

Perbedaan kedudukan hukum antara Bank Perkreditan Rakyat dengan Bank Umum sebagai pembeli didalam lelang eksekusi hak tanggungan atas jaminannya adalah Bank yang dapat membeli lelang eksekusi hak tanggungan atas jaminannya hanyalah Bank Umum sebagaimana telah diatur dalam Pasal 12 A ayat (1) Undang-Undang

\footnotetext{
${ }^{11}$ Taqiuddin, H.U. (2019). Penalaran Hukum (Legal Reasoning) Dalam Putusan Hakim. JISIP (Jurnal Ilmu Sosial dan Pendidikan), 1(2), h.193. doi: http:// dx.doi.org/10.36312/jisip.v1i2.343
} 
Perbankan termasuk didalamnya Bank Pembangunan Daerah berdasarkan Pasal 21 ayat (3) huruf c, sedangkan Bank Perkreditan Rakyat tidak dapat menjadi pembeli dalam lelang eksekusi hak tanggungan atas jaminannya.

\section{Daftar Pustaka / Daftar Referensi}

\section{Buku:}

Ali Suyanto Herli (2013), Buku Pintar Pengelolaan BPR dan Lembaga Keuangan Pembiayaan Mikro, Yogyakarta : ANDI Yogyakarta.

I Made Pasek Diantha. (2016). Metodologi Penelitian Hukum Normatif dalam Justifikasi Teori Hukum. Jakarta: Prenada Media Group. hal. 159.

Kartini Muljadi, Gunawan Widjaja, Hak Tanggungan (Seri Hukum Harta Kekayaan), Kencana : Jakarta, 2006

Rachmadi Usman. (2016). Hukum Lelang. Januari: Sinar Grafika.

\section{Jurnal:}

Jufri, S., Borahima, A., \& Said, N. (2020). Pelaksanaan Lelang Eksekusi Hak Tanggungan Melalui Balai Lelang. Jurnal Ilmiah Dunia Hukum, 4(2), 95-107. doi: http://dx.doi.org/10.35973/jidh.v4i2.1379

Lestari, C. R. (2017). Penyelesaian Kredit Macet Bank Melalui Parate Eksekusi. Kanun Jurnal Ilmu Hukum, 19(1). http://www.jurnal.unsyiah.ac.id/kanun/article/view/6600

Sumual, J. (2016). Perbedaan Bank Umum dan Bank Perkreditan Rakyat terhadap Tugas dan Fungsi Bank menurut Undang-Undang Nomor 10 Tahun 1998. Lex Administratum, 4(3).hal. https://ejournal.unsrat.ac.id/index.php/administratum/article/view/11508

Susanto, A., Rotinsulu, T. O., \& Kawung, G. M. (2019). Analisis Faktor-faktor yang Mempengaruhi Keberhasilan Lelang Eksekusi Hak Tanggungan pada Kantor Pelayanan Kekayaan Negara dan Lelang Palu (2015-September 2016). JURNAL PEMBANGUNAN EKONOMI DAN KEUANGAN DAERAH, 19(1), hal. 2. doi: https://doi.org/10.35794/jpekd.15776.19.1.2017

Taqiuddin, H. U. (2019). Penalaran Hukum (Legal Reasoning) Dalam Putusan Hakim. JISIP (Jurnal Ilmu Sosial dan Pendidikan), 1(2). doi: http://dx.doi.org/10.36312/jisip.v1i2.343

Widayati, R., \& Herman, U. (2019). Penyelesaian Kredit Bermasalah Pada PT. Bank Perkreditan Rakyat (BPR) Nagari Kasang. doi: https://doi.org/10.31219/osf.io/d738z 
Utami, P. D. Y. (2019). KAJIAN YURIDIS AGUNAN YANG DIAMBIL ALIH (AYDA) OLEH BANK. Kerta Dyatmika, 16(2), 69-77. doi: https://doi.org/10.46650/kd.16.2.739.69-77

\section{Peraturan Perundang-undangan:}

Vendu Reglement, Ordonantie 28 Februari 1908 Staatsblad 1908:189 sebagaimana telah beberapa kali diubah terakhir dengan Staatsblad 1941:3.

Undang-Undang Republik Indonesia Nomor 5 Tahun 1960 tentang Peraturan Dasar Pokok-Pokok Agraria (Lembaran Negara Republik Indonesia Tahun 1960 Nomor 104, Tambahan Lembaran Negara Republik Indonesia Nomor 2043).

Undang-Undang Republik Indonesia Nomor 4 Tahun 1996 tentang Hak Tanggungan Atas Tanah Beserta Benda-Benda yang Berkaitan dengan Tanah (Lembaran Negara Republik Indonesia Tahun 1996 Nomor 42, Tambahan Lembaran Negara Republik Indonesia Nomor 3632).

Undang-Undang Republik Indonesia Nomor 10 Tahun 1998 tentang Perubahan Atas Undang-Undang Nomor 7 Tahun 1992 tentang Perbankan (Lembaran Negara Republik Indonesia Tahun 1998 Nomor 182, Tambahan Lembaran Negara Republik Indonesia Nomor 3790).

Undang-Undang Republik Indonesia No. 13 Tahun 1962 tentang Ketentuan-Ketentuan Pokok Bank Pembangunan Daerah.

Undang-Undang Republik Indonesia Nomor 12 tahun 2011 tentang Pembentukan Peraturan Perundang-undangan (Lembaran Negara Republik Indonesia Tahun 2011 Nomor 82, Tambahan Lembaran Negara Republik Indonesia Nomor 5234).

Peraturan Menteri Keuangan Republik Indonesia Nomor 27/PMK.06/2016 tentang Petunjuk Pelaksanaan Lelang (Berita Negara Republik Indonesia Tahun 2016 Nomor 270).

Peraturan Menteri Keuangan Republik Indonesia Nomor 90/PMK.06/2016 tentang Pedoman Pelaksanaan Lelang dengan Penawaran Secara Tertulis Tanpa Kehadiran Peserta Lelang Melalui Internet (Berita Negara Republik Indonesia Tahun 2016 Nomor 818). 